\title{
ZAŠTITA KRŠKIH IZVORIŠTA VODE ZA PIĆE U ISTRI IZGRADNJOM SUSTAVA ODVODNJE ZA MALA RURALNA NASELJA
}

\author{
PROTECTION OF KARST SPRINGS USED FOR \\ WATER SUPPLY IN ISTRIA BY BUILDING SEWAGE \\ SYSTEMS FOR SMALL RURAL SETTLEMENTS
}

\author{
Gabrijela Kablar*, Martina Fabić*, Barbara Karleuša*, Goran \\ Volf*
}

\begin{abstract}
Sažetak
Odvodnja otpadnih voda u Republici Hrvatskoj s ukupno 6.762 naselja grupirana je u 736 aglomeracija, od čega 468 aglomeracija ima opterećenje do 2.000 ekvivalent stanovnika (ES). Iako se zahtjevi Direktive o pročišćavanju komunalnih otpadnih voda odnose provenstveno na aglomeracije veće od 2.000 ES, neophodno je adekvatno zbrinjavati otpadne vode i manjih aglomeracija, pogotovo u osjetljivim područjima kao što su zone sanitarne zaštite izvorišta vode za piće. U cilju zaštite izvorišta vode u Istarskoj županiji izrađena je studija „Organizacija, izgradnja i održavanje sustava odvodnje i pročišćavanja otpadnih voda za mala naselja u obuhvatu vodozaštitnih područja u Istarskoj županiji" te je osnovano trgovačko društvo IVS - Istarski vodozaštitni sustav d.o.o., koje je u vlasništvu svih gradova i općina Istarske županije čiji je zadatak realizacija navedene Studije. Studija obuhvaća 173 naselja u zonama sanitarne zaštite izvorišta vode za piće na području Istre, u kojima živi oko 38.000 stanovnika. U ovom radu će se prikazati rješenja dvaju sustava odvodnje otpadnih voda za mala naselja u Istri koja su izrađena u okviru dvaju diplomskih radova: sustav za naselje Loborika i sustav za naselja Rapavel, Anžići i Smolići. Cilj rada je istaknuti problematiku zaštite izvorišta vode za piće u kršu, mogućnosti zaštite izvorišta izgradnjom odgovarajućih sustava odvodnje i uređaja za pročišćavanje otpadnih voda, probleme koji se javljaju pri projektiranju razdjelnih sustava odvodnje otpadnih voda za aglomeracije manje od 2.000 ES kao i probleme koji se mogu očekivati u budućnosti pri korištenju sustava.
\end{abstract}

*Građevinski fakultet Sveučilišta u Rijeci, Radmile Matejčić 3, 51000 Rijeka

E-mail: \{gabrijela.kablar, martina.fabic\}@student.uniri.hr; \{barbara.karleusa,goran.volf\}@ uniri.hr 
Ključne riječi: sustav odvodnje, uređaj za pročišćavanje otpadnih voda, Istarski vodozaštitni sustav, zaštita krških izvorišta, aglomeracije manje od 2.000 ES

\begin{abstract}
Wastewater drainage for 6.762 settlements in the Republic of Croatia is grouped in 736 agglomerations, of which 468 agglomerations have loads of up to 2.000 population eqivalent (PE). Although the requirements of the Urban Wastewater Treatment Directive apply to agglomerations of more than $2.000 \mathrm{PE}$, it is necessary to adequately dispose wastewater of these smaller agglomerations, particularly in sensitive areas such as drinking water protection zones. In order to protect drinking water sources in the Istrian County, the study "Organization, construction and maintenance of drainage and wastewater treatment systems for small settlements in drinking water protection areas of the Istrian County" was prepared and the Istrian Water Protection System Ltd., whose task is the realization of the above mentioned Study, was established. The Study included 173 settlements in the areas of drinking water protection zones, where about 38.000 inhabitants live. This paper presents the designs of two wastewater drainage systems for small settlements in Istria, which were developed within two graduation theses: for the settlement Loborika and for settlements Rapavel, Anžići and Smolici. The aim of this paper is to highlight the problem of drinking water sources protection in karst areas, the possibility of protection by construction of appropriate sewage systems and wastewater treatment plants, problems encountered in the design of separate systems for agglomerations less than 2.000 PE as well as problems that can be expected in the future when these systems will be in use.
\end{abstract}

Key words: sewerage system, waste water treatment plant, Istrian Water Protection System, protection of drinking water sources in karst regions, aglomerations with less then 2.000 PE

\title{
1. Uvod
}

U ovom radu prikazat će se problematika zaštite krških izvorišta vode za piće u Istarskoj županiji izgradnjom sustava odvodnje uključujući uređaje za pročišćavanje otpadnih voda (UPOV) za mala naselja ruralnog karaktera koja se nalaze u zonama sanitarne zaštite.

Zaštita izvorišta vode za piće (odnosno za ljudsku potrošnju) u Hrvatskoj je definirana kroz više zakonskih i podzakonskih akata od kojih su najznačajniji: Zakon o vodama [1], Pravilnik o utvrđivanju zona sanitarne zaštite izvorišta [2], Pravilnik o graničnim vrijednostima emisija otpadnih voda [3], Odluka o određivanju osjetljivih područja [4], a koji su usklađeni s europskom pravnom stečevinom.

U Zakonu o vodama [1] posebno se ističu zaštićena područja među koja se ubrajaju vodna tijela koja su namijenjena ljudskoj potrošnji i osjetljiva područja u kojima je zbog postizanja ciljeva kakvoće voda potrebno provesti 
višu razinu ili viši stupanj pročišćavanja komunalnih otpadnih voda od propisanog Pravilnikom o graničnim vrijednostima emisija otpadnih voda [3]. Također se navodi obaveza donošenja odluke o zaštiti izvorišta, odluke o odvodnji otpadnih voda i sl., dok su navedeni aspekti detaljno obrađeni u podzakonskim aktima.

Pravilnik o utvrđivanju zona sanitarne zaštite za izvorišta [2] kod zahvaćanja podzemne vode iz vodonosnika s pukotinskom i pukotinskokavernoznom poroznosti u koje se svrstavaju krška izvorišta definira četiri zone zaštite te među mjerama u III. zoni zaštite zabranjuje ispuštanje nepročišćenih otpadnih voda. Stoga je za naselja u toj i u strožim zonama neophodno graditi nepropusne sustave odvodnje te otpadne vode pročišćavati i tek nakon toga ispuštati min. u III. zoni.

Direktiva o odvodnji i pročišćavanju komunalnih otpadnih voda EU [5] se prvenstveno bavi aglomeracijama većim od 2.000 ES (ekvivalent stanovnika), dok se Pravilnikom o graničnim vrijednostima emisija otpadnih voda [3] određuje stupanj pročišćavanja otpadnih voda za aglomeracije različitih opterećenja. Za aglomeracije manje od 2.000 ES (468 aglomeracija, što čini $63 \%$ aglomeracija u $\mathrm{RH}$ ) navodi se: „Komunalne otpadne vode iz sustava javne odvodnje aglomeracija s opterećenjem manjim od 2.000 ES neovisno o osjetljivosti područja pročišćavaju se odgovarajućim pročišćavanjem prije ispuštanja otpadnih voda u prijemnik." Odgovarajuće pročišćavanje ovisi o osjetljivosti područja (vodnog tijela) u koje se otpadna voda ispušta nakon pročišćavanja.

$\mathrm{Na}$ području Istarske županije važnost odgovarajućeg zbrinjavanja otpadnih voda malih naselja ruralnog karaktera je velika s obzirom da se 173 naselja nalazi u zonama sanitarne zaštite izvorišta vode za ljudsku potrošnju.

U ovom radu će se, nakon kraćeg pregleda stanja sustava odvodnje i pročišćavanja otpadnih voda u Hrvatskoj i u Istarskoj županiji, prikazati projektna rješenja dvaju sustava odvodnje za naselja koja se nalaze u zonama sanitarne zaštite izvorišta vode za piće: sustav odvodnje otpadnih voda za naselje Loborika (uključujući naselja Radeki polje i Glavica) [6] i sustav za naselja Rapavel, Anžići i Smolići [7]. Cilj ovog rada je istaknuti problematiku zaštite izvorišta vode za piće u kršu, mogućnosti zaštite izvorišta izgradnjom odgovarajućih sustava odvodnje i UPOV-a, probleme koji se javljaju pri projektiranju razdjelnih sustava odvodnje otpadnih voda za aglomeracije manje od 2.000 ES kao i probleme koji se mogu očekivati u budućnosti vezane za pogon i održavanje tih sustava. 


\section{Pregled stanja odvodnje i zbrinjavanja otpadnih voda u Hrvatskoj}

U Hrvatskoj, od ukupne populacije koju čini 4.437 .460 stanovnika, na sustave javne odvodnje je priključeno 1.923 .000 stanovnika, odnosno 43\%, od kojih je samo 28\%, odnosno 1.245 .500 stanovnika priključeno na uređaje za pročišćavanje otpadnih voda. Od toga $7 \%$ ima samo predtretman, $5 \%$ ima prvi stupanj pročišćavanja, $15 \%$ ima drugi stupanj pročišćavanja, a samo $0,3 \%$ je priključeno na uređaj s trećim stupnjem pročišćavanja (Slika 1) [8].

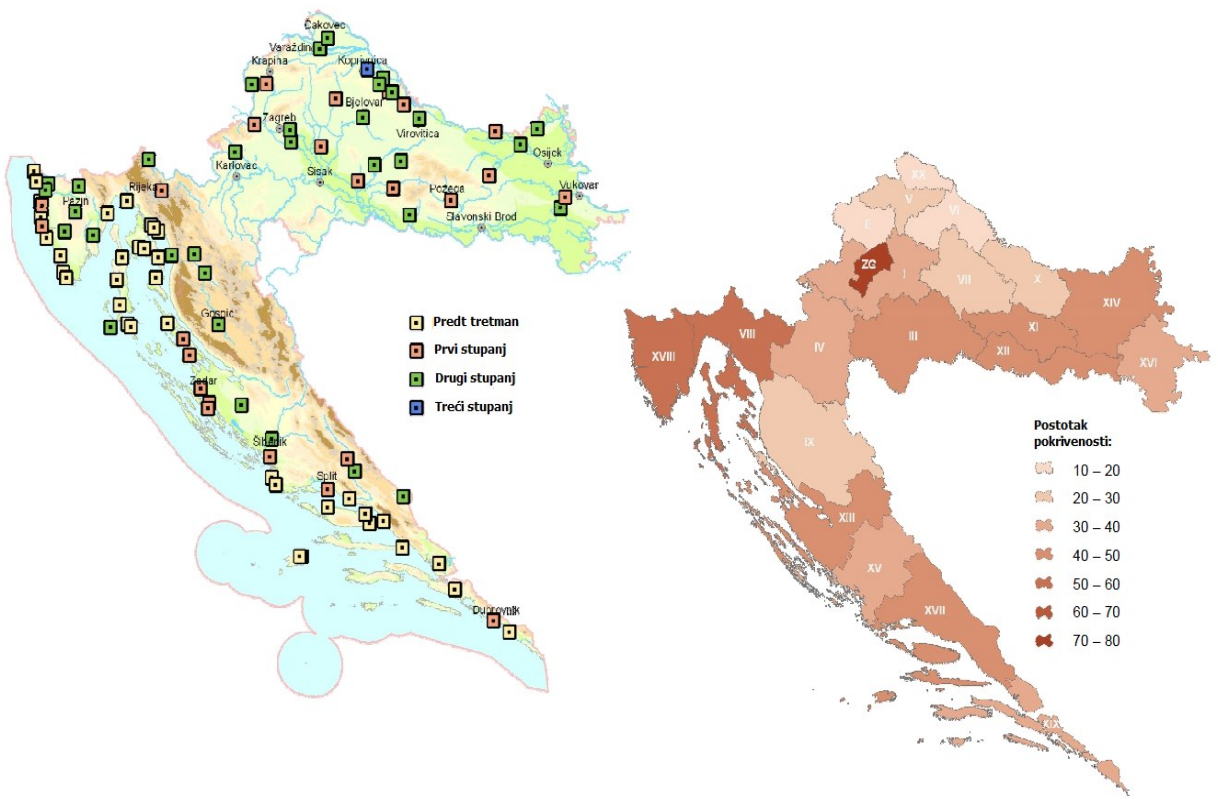

Slika 1. Pregled populacije spojene na kanalizacijski sustav te izgrađenih UPOV-a u Republici Hrvatskoj [8].

Pregled odvodnje te zbrinjavanja otpadnih voda po veličini aglomeracije prikazan je u Tablici 1 [9]. Od ukupno 6.766 naselja u Republici Hrvatskoj grupiranih u 736 aglomeracije, 468 aglomeracija, odnosno čak $63 \%$ je manje od 2.000 ES, što čini ukupno opterećenje od 421.199 ES. To opterećenje čini ukupan broj naselja od 2.649, odnosno 580.988 stanovnika. Stanovništvo je u 849 naselja priključeno na javni sustav odvodnje, dok 1.800 naselja ima individualna rješenja zbrinjavanja otpadnih voda (uglavnom septičke i sabirne jame ili individualne ispuste u cestovne i melioracijske kanale) [8]. 
Tablica 1. Pregled odvodnje te zbrinjavanja otpadnih voda u RH prema veličini aglomeracije [9].

\begin{tabular}{|c|c|c|c|c|c|c|c|}
\hline \multicolumn{2}{|c|}{$\begin{array}{c}\text { Veličina } \\
\text { aglomeracije }\end{array}$} & $0-2.000$ & $\begin{array}{l}2.001- \\
10.000\end{array}$ & $\begin{array}{l}10.001- \\
15.000\end{array}$ & $\begin{array}{l}15.001- \\
150.000\end{array}$ & $>150.000$ & Ukupno \\
\hline \multicolumn{2}{|c|}{ Broj sustava } & 468 & 205 & 31 & 51 & 4 & 759 \\
\hline \multicolumn{2}{|c|}{$\begin{array}{l}\text { Ukupno opterećenje } \\
\text { [ES] }\end{array}$} & 421.199 & 887.602 & 407.072 & 1.987 .445 & 2.001 .521 & 5.704 .839 \\
\hline \multirow{3}{*}{ 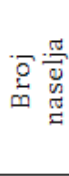 } & Sustav & 2.649 & 2.069 & 544 & 1.354 & 150 & 6.766 \\
\hline & $\begin{array}{c}\text { Javna } \\
\text { kanalizacija }\end{array}$ & 849 & 759 & 249 & 637 & 135 & 2.629 \\
\hline & $\begin{array}{l}\text { Pojedinačna } \\
\text { kanalizacija }\end{array}$ & 1.800 & 1.310 & 295 & 717 & 15 & 4.137 \\
\hline \multirow{4}{*}{$\begin{array}{l}: \frac{\pi}{0} \\
\frac{\pi}{3} \\
\frac{\pi}{0} \\
0 \\
0 .\end{array}$} & Sustav & 580.988 & 856.514 & 300.353 & 1.372 .522 & 1.327 .083 & 4.437 .460 \\
\hline & $\begin{array}{c}\text { Javna } \\
\text { kanalizacija }\end{array}$ & 366.129 & 682.829 & 258.497 & 1.277 .586 & 215 & 256 \\
\hline & $\begin{array}{r}\text { Pojedinačna } \\
\text { kanalizacija }\end{array}$ & 21 & 137.685 & 41 & 9 & 58 & 527.204 \\
\hline & Spojeno & 30.165 & 124.475 & 101.370 & 707.318 & 971.694 & 1.935 .022 \\
\hline
\end{tabular}

\section{Pregled stanja odvodnje i zbrinjavanja otpadnih voda u Istarskoj županiji}

Najveći dio Istarske županije čini vodopropusni krš. Zbog velike propusnosti pokrovnog sloja podzemlje je izrazito osjetljivo na onečišćenje s površine te je oko $70 \%$ površine Županije pod određenim režimom vodozaštite [10]. Odgovarajuće zbrinjavanje otpadnih voda naselja u Istarskoj županiji stoga predstavlja visoki prioritet. Odlukom o zonama sanitarne zaštite izvorišta vode za piće u Istarskoj županiji 2005. su definirane [11] te 2011. revidirane [12], zone koje su prikazane na Slici 2.

Prema Odluci [11], [12], za zaštitu izvorišta podzemne vode koja se koristi za javnu vodoopskrbu definirano je sljedeće:

- U IV. zoni sanitarne otpadne vode treba rješavati izgradnjom sustava javne odvodnje s drugim stupnjem pročišćavanja, a gdje nema tehničke ni ekonomske opravdanosti, otpadne vode pročišćavati na vlastitom uređaju drugog ili odgovarajućeg stupnja pročišćavanja i ispuštanjem u podzemlje putem upojnog bunara ili drenaže, odnosno ponovno koristiti za tehnološku vodu ili za potrebe navodnjavanja.

- U III. zoni sanitarne otpadne vode potrebno je prikupljati nepropusnim sustavom i odvoditi izvan zone, a gdje za to nema uvjeta, ispuštati u podzemlje nakon drugog ili odgovarajućeg stupnja pročišćavanja ili, ako je moguće, ponovo koristiti za tehnološku vodu ili za potrebe navodnjavanja. Individualni stambeni objekti na područjima gdje nema tehničke ni ekonomske opravdanosti za gradnju sustava javne odvodnje moraju imati septičku jamu ili tipski (biološki ili drugi odgovarajući) 
uređaj, s ispuštanjem otpadne vode putem upojnog bunara ili disperzivno u podzemlje.

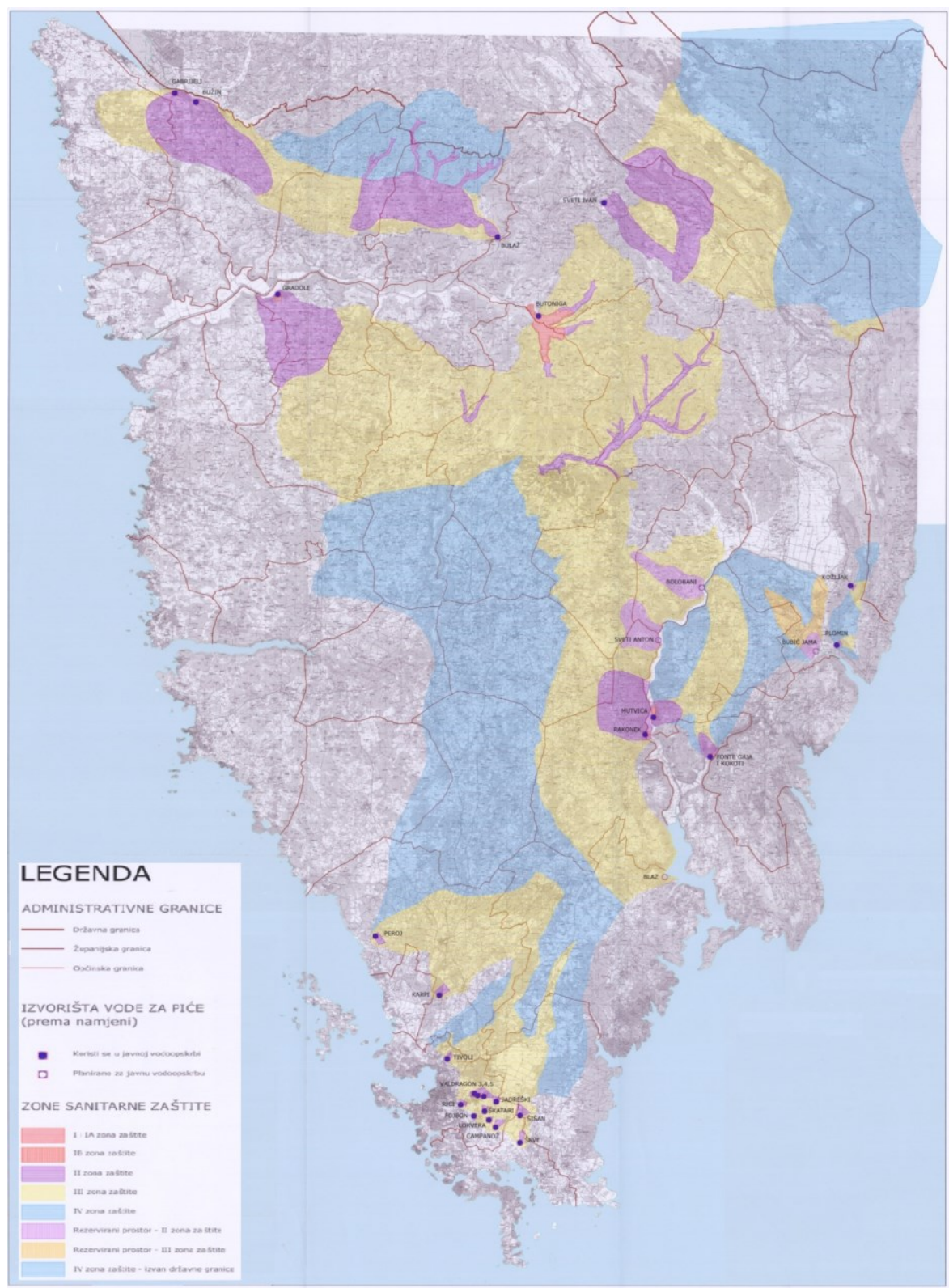

Slika 2. Zone sanitarne zaštite izvorišta vode za piće u Istarskoj županiji prema Odluci [11], [12].

- U II. zoni je za sanitarne otpadne vode obvezno izgraditi vodonepropusni sustav javne odvodnje s odvodnjom otpadne vode izvan zone te na sustav 
priključiti otpadne vode postojećih objekata ili, iznimno za mala naselja do 2.000 ES-a, izgraditi uređaj koji će pročistiti otpadne vode te izgraditi ispust, a sve u skladu s važećim propisom o graničnim vrijednostima emisija otpadnih voda. Objekti za koje nije planirano priključenje na sustav javne odvodnje moraju imati tipski uređaj drugog ili odgovarajućeg stupnja pročišćavanja s ispuštanjem otpadnih voda izvan zone ili izuzetno sakupljati otpadne vode u nepropusnu sabirnu jamu s kontrolom pražnjenja putem ovlaštenih institucija.

- U I. zoni sanitarne otpadne vode moraju se odvesti nepropusnom kanalizacijom izvan zone.

Zone sanitarne zaštite izvorišta pretežno se nalaze u unutrašnjem dijelu poluotoka gdje se, uz nekoliko gradova (npr. Pazin, Buzet), nalazi velik broj malih ruralnih naselja do $2.000 \mathrm{ES}$.

Otpadne vode u tim naseljima zbrinjavale su se u prošlosti putem crnih ili septičkih jama te u nekim slučajevima čak i direktnim ispuštanjem u okoliš. Takvo rješenje ugrožavalo je vodne resurse koji se koriste za piće te je 2000. godine u cilju zaštite izvorišta izrađena studija „Organizacija, izgradnja i održavanje sustava odvodnje i pročišćavanja otpadnih voda za mala naselja u obuhvatu vodozaštitnih područja u Istarskoj županiji" [13] koja je trebala pronaći odgovarajuća rješenja za to područje. Studija je bila temelj za osnivanje trgovačkog društva IVS - Istarski vodozaštitni sustav d.o.o., koje je u vlasništvu svih gradova i općina Istarske županije [14]. Društvo je osnovano sa zadatakom realizacije navedene Studije. Studija obuhvaća 173 naselja u zonama sanitarne zaštite izvorišta vode za piće na području Istre, u kojima živi oko 38.000 stanovnika. Kapaciteti uređaja za pročišćavanje otpadnih voda iznose od najmanje 100 do najviše 500 ES. Dosadašnje glavne aktivnosti IVS-a bile su pretežno vezane na pripremu projektne dokumentacije za kanalske mreže i UPOV-e i praćenje izgradnje, a uskoro će područje djelovanja biti i pružanje vodnih usluga.

Prema Izvješću o stanju u prostoru Istarske županije 2007-2012., u 2011. godini priključenost stanovništva Istarske županije na sustave javne odvodnje otpadnih voda bila je procjenjena na oko 57\%, a ukupan broj UPOV-a je iznosio 33 [15]. U radnoj verziji Izvješća o stanju u prostoru Istarske županije 2013.-2016. (Tablica 2) navodi se da je ukupno izgrađeno 49 UPOV-a, što je povećanje od 48\% u odnosu na stanje u 2011. godini [16]. Iz Slike 3 razvidno je da su na UPOV-ima implementirana različita tehnološka rješenja obrade otpadnih voda. Od 49 izrađenih UPOV-a, u Istarskoj županiji 30 (61\%) ima kapacitet manji od 2.000 ES. Od 13 UPOV-a izgrađenih u periodu od 2013. do 2016. godine njih 11 (85\%) izgrađeno je za aglomeracije manje od 2.000 ES pretežno ruralnog karaktera te uz 2. ili 3. stupanj pročišćavanja otpadnih voda. 
Tablica 2. Izgrađeni UPOV-i u Istarskoj županiji s navedenim stupnjem i vrstom pročišćavanja [16].

\begin{tabular}{|c|c|c|c|}
\hline Naziv (lokacija) UPOV & $\begin{array}{l}\text { Izvedeni } \\
\text { kapacitet } \\
\text { (ES) }\end{array}$ & $\begin{array}{l}\text { Izvedeni stupanj } \\
\text { pročišćavanja }\end{array}$ & Tip UPOV-a \\
\hline UPOV CUVI & 64.900 & $\mathrm{P}$ & mehanički predtretman \\
\hline UPOV VALKANE (G. Pula) & 35.000 & $\mathrm{P}$ & mehanički predtretman \\
\hline UPOV MARLERA & 34.500 & $\mathrm{P}$ & mehanički predtretman \\
\hline UPOV SAVUDRIIA & 33.000 & $\mathrm{P}$ & mehanički predtretman \\
\hline UPOV UMAG & 33.000 & $\mathrm{P}$ & mehanički predtretman \\
\hline UPOV NOVIGRAD & 33.000 & 1 & mehaničko-kemijski \\
\hline UPOV POREČ IUG & 26.000 & $\mathrm{P}$ & mehanički predtretman \\
\hline UPOV POREČ-SIEVER & 24.000 & $\mathrm{P}$ & mehanički predtretman \\
\hline UPOV PETALON & 18.000 & 1 & mehaničko-kemijski \\
\hline UPOV LANTERNA & 16.400 & $\mathrm{P}$ & mehanički predtretman \\
\hline UPOV PEROI & 14.000 & $\mathrm{P}$ & mehanički predtretman \\
\hline UPOV PREMANTURA & 8.400 & $\mathrm{P}$ & mehanički predtretman \\
\hline UPOV LABIN & 7.500 & 2 & klasični biološki \\
\hline UPOV BUZET & 7.200 & 2 & biološki \\
\hline UPOV PAZIN & 7.000 & 2 & biološki \\
\hline UPOV BUMBIŠTE & 7.000 & $\mathrm{P}$ & mehanički predtretman \\
\hline UPOV DUGA UVALA & 5.500 & $\mathrm{P}$ & mehanički predtretman \\
\hline UPOV BUIE & 4.000 & 2 & biološki \\
\hline UPOV ČERVAR-PORAT & 3.600 & 2 & biološki \\
\hline UPOV KANFANAR & 1.900 & 3 & MBR \\
\hline UPOV OPĆINE BALE & $2 \times 750$ & 3 & MBR \\
\hline UPOV POTPIĆAN & 1.150 & 2 & klasični biološki \\
\hline UPOV BRTONIGLA & 1.000 & 2 & bio-disk \\
\hline UPOV ROČ & $2 \times 500$ & 3 & MBR \\
\hline UPOV OTOK SV. NIKOLA & 700 & $\mathrm{P}$ & mehanički predtretman \\
\hline UPOV ŽMINI & 700 & 2 & biljka-uređaj \\
\hline UPOV GROŽNIAN & 500 & 2 & bio-disk \\
\hline UPOV KOROMAČNO & 500 & 2 & klasični biološki \\
\hline UPOV NOVA VAS & 400 & 2 & bio-uređaj \\
\hline UPOV OPRTALI & 400 & 3 & MBR \\
\hline UPOV VIŽINADA & $2 \times 200$ & 3 & MBR \\
\hline UPOV PRHATI & $2 \times 200$ & 3 & MBR \\
\hline UPOV RUDANI & $2 \times 200$ & 3 & MBR \\
\hline UPOV TOPIT & $2 \times 200$ & 3 & MBR \\
\hline UPOV BARBAN & 350 & 2 & bio-disk \\
\hline UPOV KAŠĆERGA & $2 \times 150$ & 2 & bio-tip \\
\hline UPOV VRH & $2 \times 150$ & 2 & bio-tip \\
\hline UPOV PLOMIN LUKA & 300 & 2 & bio-disk \\
\hline UPOV GRAČIŠĆE & 265 & 3 & MBR \\
\hline UPOV PIĆAN & 250 & 2 & klasični biološki \\
\hline UPOV VIŠNIAN & 200 & 2 & bio-disk \\
\hline UPOV SV. LOVREČ & 200 & 3 & MBR \\
\hline UPOV IND. ZONA ŽMINI & 200 & 2 & SBR \\
\hline UPOV CESARI-BAŠIĆI & 150 & 3 & MBR \\
\hline UPOV VIŠKOVIĆI & 100 & 3 & MBR \\
\hline UPOV MARČENEGLA & 100 & 3 & AA MBR \\
\hline UPOV GRDOSELO & 100 & 3 & SBR \\
\hline UPOV ŠĆULCI-PALADINI & 100 & 2 & bio-tip \\
\hline UPOV DRAGUĆ & 100 & 2 & bio-tip \\
\hline UKUPNO & 396.365 & & \\
\hline
\end{tabular}

UPOV izgrađeni u razdoblju 2013.-2016.god.

(Izvor podataka: Trgovačka društva za javnu odvodnju, općine i PPIŽ) 


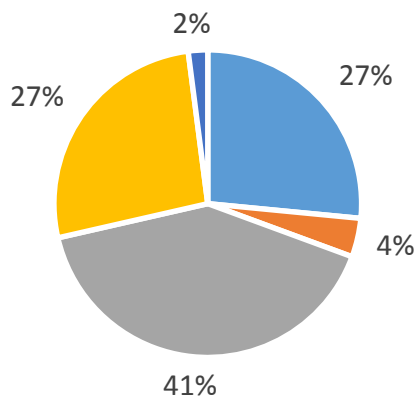

- Mehanički predtretman

- Mehaničko-kemijski

- Biološki (klasični, bio-disk, bio-tip, SBR)

$\because \mathrm{MBR}$

- Biljni

Slika 3. Pregled udjela pojedinih tipova (tehnoloških rješenja) UPOV-a u Istarskoj županiji.

Prema Studiji [13] bilo je planirano u prvoj fazi ukupno izgraditi kanalizacijsku mrežu s UPOV-ima za 86 malih naselja.

Iz podataka prikazanih u Tablici 3. jasno se vidi da se kontinuirano ulaže u izgradnju sustava odvodnje te da je u periodu od 2013. do 2016. godine izgrađeno preko $247 \mathrm{~km}$ kanalske mreže, odnosno da je duljina mreže ukupno povećana za oko $24 \%$.

Tablica 3. Duljina kanalske mreže u 2013., 2014. i 2015. godini, ukupan porast duljine mreže i postotak izrađene mreže u periodu 2013-2016 [16].

\begin{tabular}{|l|c|c|c|c|c|c|}
\hline $\begin{array}{l}\text { Trgovačka društva i općine } \\
\text { nadležne za javnu } \\
\text { odvodnju }\end{array}$ & $\begin{array}{c}\mathbf{2 0 1 3 .} \\
\mathbf{( k m )}\end{array}$ & $\begin{array}{c}\mathbf{2 0 1 4 .} \\
\mathbf{( k m )}\end{array}$ & $\begin{array}{c}\mathbf{2 0 1 5 .} \\
\mathbf{( k m )}\end{array}$ & $\begin{array}{c}\mathbf{2 0 1 6 .} \\
\mathbf{( k m )}\end{array}$ & $\begin{array}{c}\text { Ukupan } \\
\text { porast } \\
\text { duljine } \\
\text { mreže } \\
\text { (km) }\end{array}$ & $\begin{array}{c}\text { \% } \\
\text { porasta } \\
\text { duljine } \\
\text { mreže }\end{array}$ \\
\hline Park odvodnja d.o.o. Buzet & 26,95 & 27,03 & 29,23 & 29,26 & 2,31 & 9 \\
\hline Usluga odvodnja d.o.o. Pazin & 36,45 & 36,45 & 37,76 & 42,46 & 6,01 & 16 \\
\hline Pragrande d.o.o. Pula & 402,30 & 414,72 & 425,59 & 459,45 & 57,12 & 14 \\
\hline 6. maj odvodnja d.o.o. Umag & 189 & 192 & 195 & 198 & 9 & 5 \\
\hline $\begin{array}{l}\text { IVS-Istarski vodozaštitni } \\
\text { sustav d.o.o. Buzet }\end{array}$ & 12,21 & 22,14 & 24,02 & 36,41 & 24,2 & 198 \\
\hline Odvodnja Rovinj d.o.o. Rovinj & 56 & 60 & 60 & 63 & 7 & 13 \\
\hline Odvodnja Poreč d.o.o. Poreč & 166,53 & 167,33 & 212,21 & 263,47 & 96,94 & 58 \\
\hline Mandalena d.o.o.Marčana & 4,07 & 4,51 & 4,96 & 5,09 & 1,02 & 25 \\
\hline$*$ Općina Žminj & $*$ & $*$ & $*$ & 5,72 & - & - \\
\hline Limska Draga d.o.o. Kanfanar & 6,71 & 7,92 & 7,92 & 7,92 & 1,21 & 18 \\
\hline Vodovod Labin d.o.o. & 97,86 & 97,86 & 97,86 & 97,86 & - & 0 \\
\hline Albanež d.o.o. & 39 & 47 & 59 & 73 & 34 & 87 \\
\hline$* *$ Općina Bale & $* *$ & $* *$ & $* *$ & 2,82 & - & - \\
\hline Općina Barban & 8,87 & 8,87 & 8,87 & 8,87 & 0 & 0 \\
\hline Općina Gračišće & 2,80 & 2,80 & 2,80 & 2,80 & 0 & 0 \\
\hline UKUPNO & $1.048,75$ & $1.088,63$ & $1.165,22$ & $1.296,13$ & 247,38 & 24 \\
\hline
\end{tabular}

* općina Žminj: nema podatka o duljini kanalizacijske mreže u 2013., 2014., i 2015. god.

**općina Bale: u razdoblju 2013.-2016. izgrađeno 0,52 km kanalizacijske mreže

(Izvor podataka: Trgovačka društva za javnu odvodnju (javni isporučitelji vodne usluge javne odvodnje i općine) 
Intenzivna je bila izgradnja sustava odvodnje u većim gradovima Poreč $(96,94 \mathrm{~km})$ i Pula $(57,12 \mathrm{~km})$ te općini Medulin (34 km), kao i izgradnja sustava odvodnje malih naselja za koju je nadležan IVS $(24,2 \mathrm{~km})$ i kod koje je došlo gotovo do utrostručenja njene duljine (produljenje za oko 200\%).

\section{Primjeri rješavanja sustava odvodnje otpadnih voda malih naselja u zonama sanitarne zaštite u Istri}

Za prikaz rješenja odvodnje otpadnih voda malih ruralnih naselja u Istarskoj županiji, koja se nalaze u prostoru zona sanitarne zaštite izvorišta vode za piće, odabrana su dva primjera: sustav odvodnje za naselje Loborika i sustav odvodnje za naselja Rapavel, Anžići i Smolići (Slika 4). Projektna rješenja su izrađena u [6] i [7].

Pri izradi rješenja poštovale su se odredbe Prostornog plana Istarske županije, općinskih prostornih planova uređenja (Općine Marčana i Općine Višnjan), Odluka o zonama sanitarne zaštite izvorišta vode za piće Istarske županije [11], [12], studija „Organizacija, izgradnja i održavanje sustava odvodnje i pročišćavanja otpadnih voda za mala naselja u obuhvatu vodozaštitnih područja u Istarskoj županiji" [13] te svi relevantni zakoni i podzakonski akti. Temeljem navedenih dokumenata odvodnja otpadnih voda za navedena naselja treba se rješavati modelom razdjelne kanalizacije, što znači da se sanitarna otpadna voda odvodi odvojenim sustavom od oborinske vode te se treba obraditi na UPOV-ima s odgovarajućim pročišćavanjem.

Naselje Loborika nalazi se unutar III. zone sanitarne zaštite bunara: Valdragon i Jadreški, a naselja Rapavel, Anžići i Smolići u III. zoni sanitarne zaštite izvora Gradole.

Prema Pravilniku o graničnim vrijednostima emisija otpadnih voda [3], standard za efikasnost pročišćavanja otpadnih voda za III. zonu sanitarne zaštite za aglomeracije manje od 10.000 ES predviđa:

- suspendirane tvari - min. smanjenje ulaznog opterećenja 90\% ili koncentracija na izlazu $\leq 35 \mathrm{mg} / \mathrm{l}$

- biokemijska potrošnja kisika $\mathrm{BPK}_{5}$ - min. smanjenje ulaznog opterećenja $70 \%$ ili koncentracija na izlazu $\leq 25 \mathrm{mgO}_{2} / \mathrm{l}$

- kemijska potrošnja kisika KPK - min. smanjenje ulaznog opterećenja $75 \%$ ili koncentracija na izlazu $\leq 125 \mathrm{mg} / \mathrm{l}$.

Hidraulički proračun oba sustava odvodnje je proveden u računarskom programu Urbano Canalis tvrtke Studio ARS d.o.o., statički proračun cijevi 
korištenjem računarskog programa Vargon istoimene tvrtke te crpki korištenjem računarskog programa WebCAPS tvtke Grundfos.

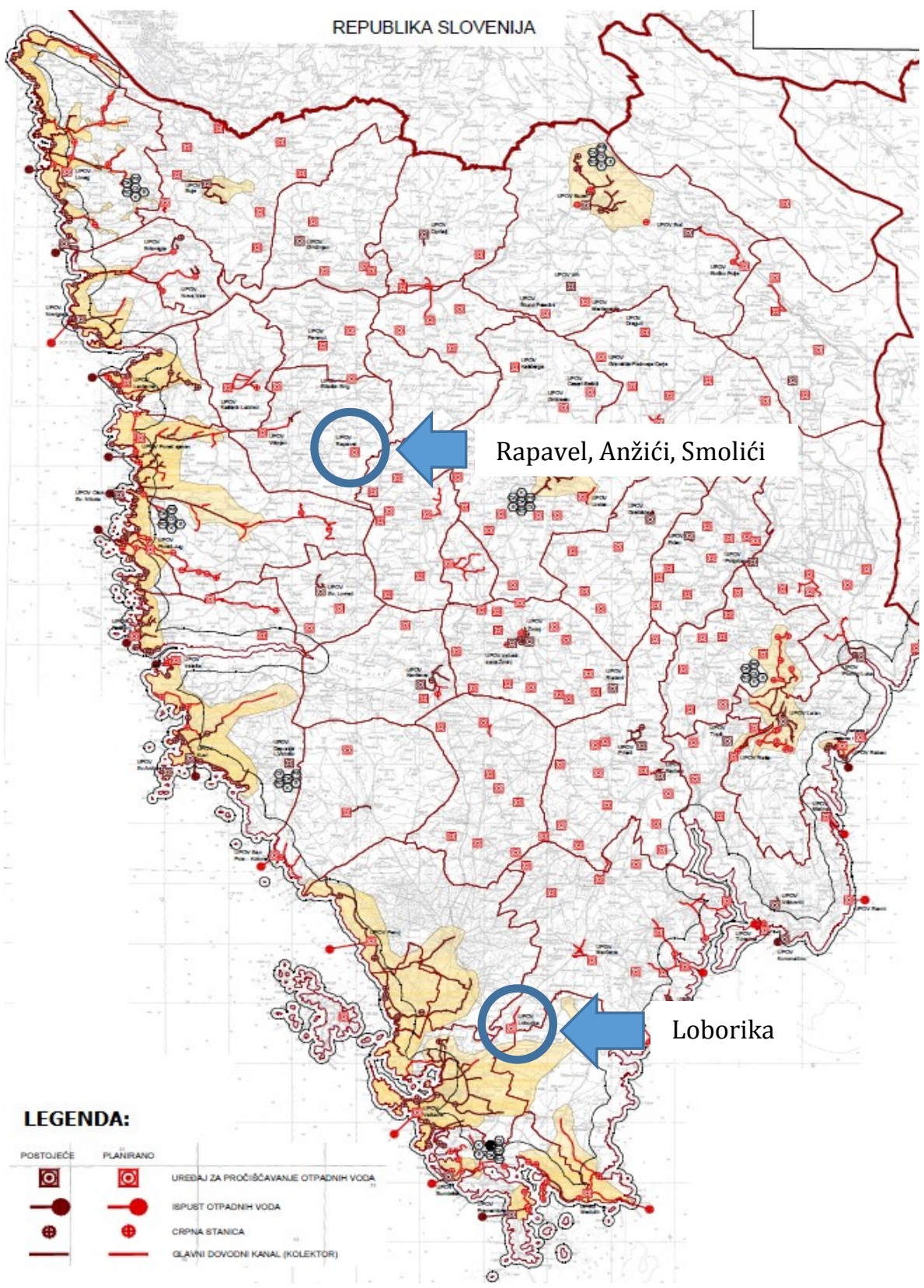

Slika 4. Infrastrukturni sustavi, odvodnja otpadnih voda i sustav godspodarenja otpadom, [17], uz naznačena naselja Loborika i Rapavel, Anžići i Smolići. 


\subsection{Zbrinjavanje otpadnih voda naselja Loborika}

Prema Studiji [13], za naselje Loborika, koje se nalazi u Općini Marčana, predviđena je gradnja MBR (membranski bioreaktor) uređaja kapaciteta 1.000 ES kojim se postiže izuzetno visoka učinkovitost pročišćavanja.

U rješenju koje je izrađeno u [6] rješava se odvodnja naselja Loborika, ali i obližnjih naselja Radeki polje i Glavica. Opterećenje na UPOV-u na kraju 30 godišnjeg projektnog razdoblja definirano je u većem iznosu od onog navedenog u Studiji [13]. Naime, ukupan broj stanovnika prema popisu stanovništva iz 2011. iznosi 844 stanovnika te, ukoliko se uzme u obzir relativni porast broja stanovnika dobiven u odnosu na broj stanovnika iz popisa 2001., on iznosi $4,68 \%$, što bi na kraju 30-godišnjeg projektnog razdoblja za sva tri naselja bilo 3.328 stanovnika. Predviđa se i boravak 343 turista.

Temeljem postavljanja trase sustava odvodnje naselja Loborika, položaj UPOV-a bio je unaprijed definiran prema Prostornom planu Istarske županije (Slika 4). Pri izradi rješenja, u radu [6] se maksimalno primjenjivao gravitacijski način odvodnje, ali je na pojedinim mjestima zbog konfiguracije terena bilo nemoguće funkcionalno spojiti pojedine dijelove naselja gravitacijski na glavni kanal te je na tim mjestima predviđena gradnja crpnih stanica s pripadnim tlačnim cjevovodima (Slika 5). Ukupna duljina gravitacijskih kanala projektiranog sustava iznosi $11.800 \mathrm{~m}$, a ukupna duljina tlačnih kolektora iznosi $1.460 \mathrm{~m}$. Na mreži se nalazi preko 300 revizijskih i 21 kaskadno okno.

Odabrane su cijevi i okna od polietilena visoke gustoće koji se karakterizira kao elastični materijal, tzv. PEHD cijevi. Za gravitacijski kolektor odabiru se orebrene cijevi tvrtke Vargon, prepoznatljive po vanjskoj orebrenoj površini crne boje te glatkoj i svijetlo zelenoj unutrašnjosti cijevi. Hidrauličkim proračunom definiran je profil cijevi za gotovo cijeli sustav s DN 250 te iznimno jedna dionica s DN 315, neposredno prije UPOV. Tlačni kolektor izvodi se od cijevi Vargoplen. Odabiru se cijevi PN 10 profila DN 90. Odabiru se revizijska okna koja su također iz iste serije proizvoda kao i odabrane cijevi. Budući da su odabrane cijevi profila DN 250 i DN 315, revizijska okna se postavljaju na udaljenostima manjim od $50 \mathrm{~m}$.

Projektom se predviđa 6 crpnih stanica kojima se savladavaju visinske prepreke. Crpne stanice izvode se kao male tipske. Svaka crpna stanica oprema se dvjema potopljenim crpkama, potrebnim armaturnim i oblikovnim komadima, ima otvor za ventilaciju i otvor za održavanje, nadzor i rukovanje crpkama. Crpni bazen izvodi se od prefabriciranih betonskih elemenata koji oblikuju vodonepropusnu konstrukciju. Odabrane su centrifugalne potopne crpke proizvođača Grundfos koje su prilagođene 
potiskivanju otpadnih nepročišćenih voda. Pumpe se u radu izmjenjuju pa u slučaju kvara jedne, rad se automatski prebacuje na drugu pumpu.



Slika 5. Pregledna situacija sustava odvodnje i UPOV-a naselja Loborika [6].

\subsection{Naselja Rapavel, Anžići i Smolići}

Naselja Rapavel, Anžići i Smolići nalaze se u Općini Višnjan i trenutno nemaju izgrađen sustv odvodnje otpadnih voda, no uskoro se očekuje početak izgradnje. Gradnja sustava financirana je EU fondovima, i to Programom ruralnog razvoja RH 2017-2020.

Prema Studiji [13], predviđena je gradnja BIOTOP uređaja za biološko pročišćavanje kapaciteta 200 ES kojim se postiže 2. stupanj pročišćavanja, a uređaj će biti smješten na području naselja Anžići s ispuštanjem pročišćene vode $u$ teren.

U radu [7] se predviđa da će zbog planirane veličine građevinskog zemljišta i uslijed poticanja razvoja ruralnih područja na kraju projektnog razdoblja od 30 godina broj stanovnika sa 88 porasti na 255 unatoč 
sadašnjem trendu opadanja broja stanovnika (prema podatcima iz popisa stanovništva RH 2001. i 2011.) te je procijenjeni broj turista 48.

Tijekom izrade projektnog rješenja kanalske mreže sustava odvodnje težilo se vođenju kanala paralelno s padom terena i na minimalnoj dubini polaganja kako bi se osiguralo otjecanje otpadne vode sa slobodnim vodnim licem. Za gravitacijske kolektore odabrane su PEHD cijevi profila DN 250, a za tlačne cijevi DN 110 (Slika 6.). Revizijska okna od istog materijala postavljena su na početku i na kraju svakog kanala, u skretanjima na priključcima te u pravcu maksimalno svakih $50 \mathrm{~m}$ zbog minimalnog profila cijevi DN 250. Svi kanali su polagani u koridoru prometnica, neasfaltiranih putova te neobrađenih zemljišta.

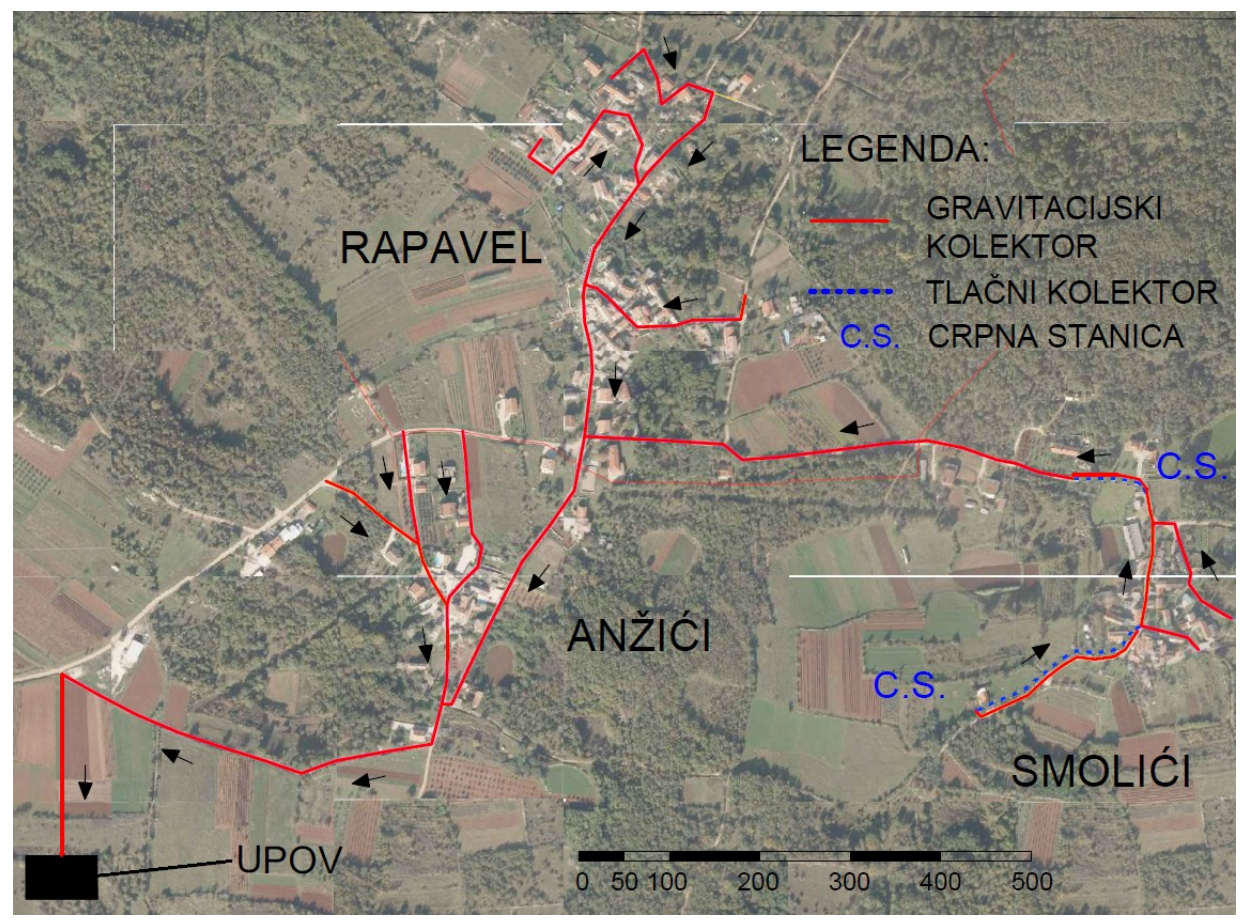

Slika 6. Pregledna situacija sustava odvodnje i UPOV-a za naselja Rapavel, Anžići i Smolići [7].

Ukupna duljina gravitacijskih kolektora iznosi 4.075 m, tlačnih 310 m, broj revizijskih okana je 130, a kaskadnih 3 . Sustav odvodnje karakteriziraju i kaskadna okna koja se ugrađuju s ciljem postizanja prekida padova usljed kojih će doći do pada energije toka otpadne vode i polaganja kanala $s$ manjim uzdužnim padovima, a time i smanjenja brzine toka vode. Uz kaskadna okna, u sustavu su interpolirane i dvije crpne stanice na području naselja Smolići. 


\subsection{Problematika projektiranja i korištenja sustava odvodnje otpadnih voda malih naselja}

Nakon definiranja obima mreže, prvi korak u projektiranju sustava odvodnje je odrediti mjerodavne protoke otpadne vode za što je neophodno pretpostaviti broj stanovnika koji će biti priključen na mrežu na kraju projektnog razdoblja. Budući da često nema dostupnih podataka o godišnjem prirastu stanovništva čak niti iz prostornih planova, potrebno je broj prognoziranih stanovnika odrediti koristeći različite metodologije. U radovima [6] i [7] korišten je pristup analize pozitivnog prirasta broja stanovnika kroz zadnjih 10 godina (između dva popisa stanovništva) za naselje Loborika, dok je za naselja Rapavel, Anžići i Smolići taj prirast prema popisima stanovništva negativan te je u tom slučaju porast broja stanovnika procijenjen uzevši u obzir trend razvoja ruralnih prostora na području Istarske županije (uslijed mnogobrojnih financijskih poticaja za ruralni razvoj) i proširenja građevinskog područja.

Kod projektiranja razdjelnog sustava odvodnje otpadnih voda za mala naselja najveći problem predstavlja ograničenje minimalnih profila cijevi koje iznosi DN 250. Izradom oba projektna rješenja za odvodnju sanitarnih otpadnih voda naselja dobiveni su mali protoci te je profil cijevi s DN 250 na većem dijelu mreže predimenzioniran. Zbog malih potoka i ograničenja minimalnih profila cijevi, brzine tečenja su vrlo male.

S druge strane, pri definiranju pada nivelete (visinsko-vertikalno vođenje trase) pokušava se u što većoj mjeri pratiti pad terena kako bi se racionalizirali troškovi iskopa. Međutim, hidrauličkim proračunom dobivaju se neprihvatljivo male brzine pa nije moguće niveletom pratiti liniju terena, nego se niveletu postavlja na način da se zadovolji minimalna brzina u cijevima od $0,5 \mathrm{~m} / \mathrm{s}$, poštuju ograničenja dubine ugradnje cijevi i ograničenja uzdužnih padova. Minimalna dubina ugradnje cijevi mjereno od tjemena cijevi iznosi $1 \mathrm{~m}$, a maksimalna dubina ugradnje $6 \mathrm{~m}$. Kako bi se zadovoljila sva nabrojana ograničenja, dubine polaganja cijevi se znatno povećavaju.

Održavanje sustava odvodnje ima vrlo važnu ulogu u njezinom pravilnom funkcioniranju pogotovo u ovakvim projektnim rješenjima gdje su protoci mali i gdje se dobivaju minimalne brzine tečenja te je velika mogućnost pojave taloženja i začepljenja pa je potrebno planirati redovito ispiranje mreže na kritičnim dionicama. 


\section{Zaključak}

U ovom radu prikazana je problematika zaštite krških izvorišta vode za piće u Istarskoj županiji izgradnjom sustava odvodnje i UPOV-a za mala naselja ruralnog karaktera koja se nalaze u zonama sanitarne zaštite.

Konkretna problematika detaljnije je prikazana na projektnim rješenjima sustava odvodnje naselja Loborika i naselja Rapavel, Anžići i Smolići u Istarskoj županiji. Izgradnjom sustava odvodnje i UPOV-a omogućuje se kontrolirana odvodnja, pročišćavanje i ispuštanje pročišćenih otpadnih voda u okoliš, zaštita okoliša i izvorišta vode za piće te se podiže i kvaliteta života stanovništva.

Temeljem analize projektnih rješenja može se zaključiti da je pri projektiranju sustava odvodnje sanitarnih otpadnih voda aglomeracija manjih od 2.000 ES izuzetno teško zadovoljiti ograničenja projektnih parametara kanalizacijske mreže (ograničenja minimalnih profila, ograničenja profila, ograničenja uzdužnih padova, ograničenja dubine ugradnje kanala) te da oni često znatno povećavaju ukupne troškove izgradnje, pogona i održavanja cjelovitih sustava. Zbog povećanih količina iskopa povećavaju se troškovi izgradnje sustava odvodnje, ali se povećavaju i troškovi održavanja jer treba provoditi učestalija ispiranja kanalske mreže. No, s obzirom da se njima provodi zaštita izuzetno važnog resursa, a to je voda za piće, ekonomska opravdanost u ovom slučaju nije prioritet.

Zahvala. Ovaj je članak rezultat rada u okviru potpore Sveučilišta u Rijeci (naslov: Razvoj novih metodologija u gospodarenju vodama i tlom u krškim, osjetljivim i zaštićenim područjima; broj potpore 13.05.1.3.08).

\section{Literatura}

[1] Zakon o vodama (NN 153/09, 130/11, 53/13, 14/14)

[2] Pravilnik o utvrđivanju zona sanitarne zaštite izvorišta (NN 66/11,47/13)

[3] Pravilnik o graničnim vrijednostima emisija otpadnih voda (NN $80 / 13,43 / 14,27 / 15$ i 3/16)

[4] Odluka o određivanju osjetljivih područja (NN 81/10 i 141/15)

[5] Direktiva o odvodnji i pročišćavanju komunalnih otpadnih voda (91/271/EEC)

[6] Kablar, G. Odvodnja sanitarnih otpadnih voda naselja Loborika, Diplomski rad, Građevinski fakultet u Rijeci, 2017.

[7] Fabić, M. Odvodnja i pročišćavanje sanitarnih otpadnih voda naselja Rapavel, Anežići i Smolići, Diplomski rad, Građevinski fakultet u Rijeci, 2017. 
[8] Requirements of the Urban Waste Water Treatment Directive and the Water Framework Directive Ways towards an Integrated Implementation in an Accession State Example Republic of Croatia. First Report. 2008.

[9] Popović, I. Implementation of the Water Framework Directive and Urban Waste Water Treatment Directive in the Republic of Croatia - Costs - Investments, Operation/Maintenance Adaptation. Hrvatske vode. URL: http://www.wfdcroatia.eu/templates/radnaEng.asp?sifraStranica=564\#urban, (pristupljeno 14.12.2017.)

[10] Županijska razvojna strategija Istarske županije 2011.-2013., Službene novine Istarske županije 10/2011.

[11] Odluka o zonama sanitarne zaštite izvorišta vode za piće u Istarskoj županiji, Službene novine Istarske županije 12/2005.

[12] Odluka o izmjeni i dopuni Odluke o zonama sanitarne zaštite izvorišta vode za piće u Istarskoj županiji, Službene novine Istarske županije 2/2011.

[13] „Organizacija, izgradnja i održavanje sustava odvodnje i pročišćavanja otpadnih voda za mala naselja u obuhvatu vodozaštitnih područja u Istarskoj županiji", Studija, naručitelj: Istarska županija, izradio: TEH-PROJEKT HIDRO d.o.o., Rijeka, 2000.

[14] http://www.ivsustav.hr/ (pristupljeno 14.12.2017.)

[15] Izvješće o stanju u prostoru Istarske županije 2007-2012, Zavod za prostorno planiranje Istarske Županije, Pula, 2013.

[16] Izvješće o stanju u prostoru Istarske županije 2013-2016, Zavod za prostorno planiranje Istarske Županije, Pula (radna verzija)

[17] https://www.istra-

istria.hr/fileadmin/dokumenti/prostorni_plan/Ostali/PPIZ_2016/PPIZ_2016 S/2_3_2_odvodnja_otpadnih_voda_i_sustav_gospodarenja_otpadom_2016S.pd f (pristupljeno 14.12.2017.) 